\title{
Analisis Faktor Yang Mempengaruhi Ketepatan Masa Studi Mahasiswa Program Studi Farmasi UIN Maulana Malik Ibrahim Malang
}

\author{
Abdul Hakim*1, Yen Yen Ari Indrawijaya ${ }^{1}$ and Yuwono $^{1}$ \\ ${ }^{1}$ Fakultas Kedokteran dan Ilmu Kesehatan, UIN Maulana Malik Ibrahim Malang
}

*E-mail: ahakim@farmasi.uin-malang.ac.id

\begin{abstract}
The 70\% punctuality of graduating students is one of the quality targets of the Faculty of Medicine and Health Sciences UIN Maulana Malik Ibrahim Malang and is one of the assessment points in the LAM-PTkes accreditation. While the punctuality of graduation from the Pharmacy department FKIK UIN Malang was 20\% for the 2013 class, 17\% for the 2014 batch, 14\% for the 2015 batch and $66 \%$ for the 2016 batch. does not meet the FKIK quality standards. This study was conducted to identify the factors that affect the punctuality of graduation for Pharmacy students so that it can help the Pharmacy department to improve the punctuality of graduation. The design of this research is an observational study that is cross-sectional. The results of this study are that there is no significant relationship between motivation and timeliness of graduation for students of the pharmaceutical study program at UIN Malang, there is no significant relationship between interest and timeliness of graduation for students of Pharmacy department UIN Malang, there is no significant relationship between intelligence There is no significant relationship between spiritual intelligence and the punctuality of graduating pharmacy study students at UIN Malang and there is no significant relationship between the scientific field and the punctuality of graduating Pharmacy study program students at UIN Malang. In conclusion, none of the factors studied had a significant relationship with the punctuality of graduating students from the pharmacy department at UIN Maulana Malik Ibrahim Malang.
\end{abstract}

Keywords: punctuality of graduation, pharmacy department

\begin{abstract}
ABSTRAK
Ketepatan waktu lulus mahasiswa sebesar 70\% menjadi salah satu target mutu Fakultas Kedokteran dan Ilmu Kesehatan (FKIK) UIN Maulana Malik Ibrahim Malang dan menjadi salah satu poin penilaian dalam akreditasi LAM-PTkes. Sedangkan ketepatan waktu kelulusan Prodi Farmasi FKIK UIN Maulana Malik Ibrahim Malang sebesar 20\% untuk angkatan 2013, 17\% untuk angkatan 2014, 14\% untuk angkatan 2015 dan 66\% untuk angkatan 2016. Data tersebut menunjukkan bahwa selama ini pencapaian ketepatan waktu lulus mahasiswa Prodi Farmasi belum memenuhi standar mutu FKIK. Penelitian ini dilakukan untuk mengidentifikasi faktor yang mempengaruhi ketepatan waktu lulus mahasiswa Prodi Farmasi sehingga bisa membantu Prodi farmasi untuk meningkatkan ketepatan waktu lulus. Desain penelitian ini adalah penelitian observasional yang bersifat crossectional. Hasil penelitian ini adalah tidak terdapat hubungan yang signifikan antara motivasi dengan ketepatan waktu lulus mahasiswa program studi farmasi UIN Maulana Ibrahim Malang, tidak ada hubungan yang signifikan antara minat dengan ketepatan waktu lulus mahasiswa Prodi Farmasi UIN Maulana Ibrahim Malang, tidak ada hubungan yang signifikan antara kecerdasan sosial dengan ketepatan waktu lulus mahasiswa prodi Farmasi Uin Maulana Ibrahim Malang, tidak ada hubungan yang signifikan antara kecerdasan spiritual dengan ketepatan waktu lulus mahasiswa prodi farmasi UIN Maulana ibrahim malang dan tidak ada hubungan yang signifikan antara bidang keilmuan dengan ketepatan waktu lulus mahasiswa prodi Farmasi UIN Malang. Kesimpulannya, tidak ada faktor-faktor yang diteliti yang memiliki hubungan ynag signifikan dengan ketepatan waktu lulus mahasiswa prodi farmasi UIN Maulana Malik Ibrahim Malang.
\end{abstract}

Kata Kunci: ketepatan waktu lulus, program studi farmasi 


\section{Pendahuluan}

Berdasarkan UU No. 12 Tahun 2012 Tentang Pendidikan Tinggi, maka setiap Pendidikan Tinggi harus memiliki Sistem Penjaminan Mutu. Sistem Penjaminan Mutu Pendidikan Tinggi adalah kegiatan sistemik untuk meningkatkan mutu Pendidikan Tinggi secara berencana dan berkelanjutan. Tujuan penjaminan mutu adalah memelihara dan meningkatkan mutu pendidikan tinggi secara berkelanjutan, yang dijalankan secara internal untuk mewujudkan visi dan misi perguruan tinggi, serta untuk memenuhi kebutuhan stakeholders melalui penyelenggaraan tridharma perguruan tinggi. Hal tersebut dapat dilaksanakan secara internal oleh perguruan tinggi yang bersangkutan, dikontrol dan diaudit melalui kegiatan akreditasi yang dijalankan oleh Badan Akreditasi Nasional (BAN) Perguruan Tinggi atau lembaga lain secara eksternal. Sehingga obyektifitas penilaian terhadap pemeliharaan dan peningkatan mutu akademik secara berkelanjutan di suatu perguruan tinggi dapat diwujudkan [1].

UIN Maulana Malik Ibrahim telah memiliki sistem penjaminan mutu perguruan tinggi. Di dalamnya ada Sistem Penjaminan Mutu Internal dan Sistem Penjaminan Mutu Eksternal. Untuk Sistem Penjaminan Mutu Internal, dilakukan oleh Lembaga Penjaminan Mutu dengan melakukan audit internal enam bulan sekali. Sedangkan lembaga audit eksternal yang dilibatkan dalam proses penjaminan mutu di UIN Maulana Malik Ibrahim Malang adalah BAN-PT (Badan Akreditasi Nasional Perguruan Tinggi, LAM-PTkes (Lembaga Akreditasi Mandiri Perguruan Mandiri Perguruan Tinggi Kesehatan) serta ISO (International Standarization Organization). Saat ini UIN Maulana Malik Ibrahim telah meraih akreditasi A dari BAN-PT dan sertifikat system manajemen mutu ISO 9001:2015 [2].

Program Studi Farmasi merupakan salah satu program studi di Fakultas Kedokteran dan Ilmu kesehatan. Pada sasaran mutu Fakultas Kedokteran dan Ilmu Kesehatan UIN Maulana Malik Ibrahim Malang tahun 2020-2025, ditetapkan bahwa ketepatan waktu lulus mahasiswa sebesar $70 \%$. Demikian juga dalam pedoman penilaian dokumen kinerja LAM-PTkes, program studi akan mendapatkan nilai maksimal terkait persentase keberhasilan studi apabila mahasiswa yang lulus tepat waktu (4 tahun) berjumlah banyak. Adapun data ketepatan waktu lulus program studi farmasi FKIK UIN Maulana Malik Ibrahim Malang adalah 20\% untuk angkatan 2013, 17\% untuk angkatan 2014, 14\% untuk angkatan 2015 dan $66 \%$ untuk angkatan 2016. Data tersebut menunjukkan bahwa bahwa selama ini pencapaian ketepatam lulus tepat waktu mahasiswa Program Studi Farmasi belum memenuhi standar, baik standar pada sasaran mutu Fakultas Kedokteran dan Ilmu Kesehatan maupun standar penilaian akreditasi
LAM-PTkes. Kondisi ini tentu harus segera ada penanganan supaya tidak terjadi hal-hal yang tidak diharapkan

Kelulusan tidak tepat waktu dapat menyebabkan banyak kerugian baik bagi mahasiswa, program studi maupun universitas. Bagi mahasiswa, akan menyebabkan terlambatnya menempuh program studi profesi atau memasuki dunia kerja dan secara ekonomi akan menambah pengeluaran untuk membayar UKT (Uang Kuliah Tunggal) pada semester tambahan. Selain itu, bagi sebagian mahasiswa yang mengalami tidak tepat waktu lulus akan menjadi beban secara psikologis ketika berhadapan dengan orang tua atau wali yang membiayainya, demikian juga ketika berinteraksi dengan keluarga, teman, tetangga dan orang lainnya.

Ada banyak faktor yang berpengaruh pada keberhasilan mahasiswa. Secara umum, faktor-faktor itu bisa dikelompokkan dalam faktor internal dan faktor eksternal. Faktor-faktor internal tersebut antara lain adalah salah satu faktor yang mempengaruhi keberhasilan belajar adalah motivasi [3]. Motivasi merupakan pemasok daya untuk bertingkah laku secara terarah [4]. Faktor lain yang berpengaruh pada keberhasilan mahasiswa adalah minat [5]. Kemudaian faktor intelegensia/kecerdasan juga berpengaruh pada keberhasilan mahasiswa. Ada banyak sekali pengelompokan kecerdasan. Di antara pengelompokan tersebut antara lain adalah kecerdasan sosial dan kecerdasan spiritual. Kecerdasan sosial adalah individu yang mampu menjalin pengaruh dengan orang lain dengan lancar, peka terhadap reaksi-reaksi dan mampu membaca reaksi dan perasaan orang lain [6]. Sedangkan kecerdasan spiritual adalah kemampuan seseorang bagaimana dapat merasakan semua kegiatan yang dilakukannya dengan senang hati (ikhlas) dan selalu mengaitkannya dengan ibadah.

Faktor lain yang berpengaruh terhadap keberhasilan mahasiswa adalah faktor eksternal. Pada penelitian ini, faktor eksternal yang akan diteliti adalah bidang ilmu yang dipilih saat penelitian. Bidang ilmu di Program Studi Farmasi sebelum tahun 2020 ada empat yaitu Biologi Farmasi, Kimia Farmasi, Teknologi Farmasi serta Farmasi Komunitas dan Klinik.

Penelitian ini dilakukan di Program Studi Farmasi Fakultas Kedokteran dan Ilmu Kesehatan UIN Maulana Malik Ibrahim Malang karena penelitian serupa belum ada di program studi tersebut. Selain itu, peneliti juga ingin memberikan masukan kepada program studi Farmasi di mana peneliti beraktifitas sehari-hari. Peneliti berharap hasil penelitian ini bisa membantu dalam penyelesaian permasalahan seputar masa studi di program studi tersebut. 


\section{Bahan dan Metode}

\subsection{Rancangan Penelitian dan Waktu Pelaksanaan}

Rancangan penelitian ini adalah penelitian observasional yang bersifat crossectional. Penelitian ini dilaksanakan pada bulan Oktober - November 2020.

\subsection{Populasi, Sampel dan Teknik Pengambilan Sampel}

Populasi dalam penelitian ini adalah alumni Program Studi Farmasi UIN Maulana Malik Ibrahim Malang. Kriteria eksklusi: alumni mahasiswa dari luar negeri. Sampel penelitian adalah bagian (subset) dari populasi yang dipilih dengan cara tertentu hingga dianggap mewakili populasinya. Berdasarkan rumus, jumah sampel yang dibutuhkan yaitu 145 responden. Pemilihan sampel dilakukan dengan proportional stratified random sampling.

\subsection{Analisis Data}

Teknik analisis data yang digunakan dalam penelitian ini adalah analisis deskriptif, yang selanjutnya diolah dan dilakukan analisis hubungan. Analisis data menggunakan teknik korelasi tata jenjang atau rank correlation atau sering juga disebut dengan uji korelasi Rank Spearman. Selain itu juga mengguakan chi square dan man whitney, tergantung skala data yang diujikan.

\section{Hasil dan Pembahasan}

\subsection{Data Demografi Responden}

Data demografi responden dipaparkan dalam table 1 berikut ini:

Tabel 1. Data demografi responden berdasarkan angkatan

\begin{tabular}{llcc}
\hline & Karakteristik & Frekuensi & Persentase (\%) \\
\hline Angkatan & 2013 & 46 & 31,72 \\
& 2014 & 36 & 24,83 \\
& 2015 & 20 & 13,79 \\
& 2016 & 43 & 29,66 \\
\hline Jenis kelamin & Pria & 24,14 \\
& Wanita & 35 & 75,86 \\
\hline Jalur masuk PT & Snmptn & 110 & 28.97 \\
& Sbmptn & 42 & 37.93 \\
& Mandiri Tulis & 55 & 17.93 \\
& Mandiri Prestasi & 26 & 2.76 \\
& Lainnya & 4 & 12.41 \\
\hline BIdang ilmu yang ditekuni & Biologi Farmasi & 38.62 \\
& Kimia Farmasi & 18 & 6.21 \\
& Teknologi farmasi & 56 & 17.24 \\
& Farmasi Klinik dan Komunitas & 9 & 37.93 \\
\hline Masa studi & 8 semester & 25 & 48.97 \\
& 9 semester & 55 & 38.62 \\
& 10 semester & 71 & 9.66 \\
& 11 semester & 56 & 1.38 \\
& 12 semester & 14 & 0.00 \\
& 13 semester & 2 & 0.69 \\
\hline
\end{tabular}

Berdasarkan tabel 1 di atas dapat diketahui bahwa dari 145 responden yang berpartisipasi dalam penelitian ini, yang paling banyak adalah alumni dari angkatan 2013. Hal tersebut disebabkan karena saat ini, angkatan 2013 memiliki persentase jumlah lulusan yang terbanyak dibandingkan angkatan yang lain. Dengan demikian alumni ynag dilibatkan dalam penelitian juga paling banyak. Sedangkan berdasarkan jenis kelamin, paling banyak responden berjenis kelamin perempuan. Hal ini sesuai dengan kondisi alumni ynag menunjukkan jumlah perempuan lebih banyak daripada jumlah laki-laki. Sedangkan dilihat dari jalur masuk PT, responden yang paling banyak berasal dari jalur SBMPTN. Ini juga sesuai dengan kondisi persentase jumlah mahasiswa baru yang masuk prodi farmasi dimana yang paling banyak adalah dari jalur SBMPTN. Jadi bila dilihat karakteristik responden tersebut, sudah menunjukkan adanya kesesuaian dengan karakteristik populasi. Hal tersebut berarti pemilihan responden sudah tepat bila ditinjau beberapa karakteristik tersebut.

\subsection{Analisis}

\subsubsection{Analisis Deskriptif motivasi dengan ketepatan} masa studi

Analisis dekriptitif hubungan antara motivasi dengan ketepatan masa studi digambarkan pada tabel 2 berikut ini: 
Tabel 2. Hasil analisis deskriptif antara motivasi dengan ketepatan masa studi

\begin{tabular}{|c|c|c|c|c|c|c|c|c|c|}
\hline \multicolumn{10}{|c|}{ Motivasi * Ketepatan Masa Studi Crosstabulation } \\
\hline & & & \multicolumn{6}{|c|}{ Ketepatan Masa Studi } & \multirow[b]{2}{*}{ Total } \\
\hline & & & $\begin{array}{c}14 \\
\text { Semester }\end{array}$ & $\begin{array}{c}13 \\
\text { Semester }\end{array}$ & $\begin{array}{c}11 \\
\text { Semester }\end{array}$ & $\begin{array}{c}10 \\
\text { Semester }\end{array}$ & 9 Semester & 8 Semester & \\
\hline \multirow[t]{6}{*}{ Motivasi } & \multirow[t]{2}{*}{ Kurang } & Count & 0 & 0 & 0 & 0 & 6 & 9 & 15 \\
\hline & & $\begin{array}{l}\text { \% within } \\
\text { Motivasi }\end{array}$ & $0.00 \%$ & $0.00 \%$ & $0.00 \%$ & $0.00 \%$ & $40.00 \%$ & $60.00 \%$ & $100.00 \%$ \\
\hline & \multirow[t]{2}{*}{ Cukup } & Count & 1 & 1 & 2 & 12 & 38 & 56 & 110 \\
\hline & & $\begin{array}{l}\text { \% within } \\
\text { Motivasi }\end{array}$ & $0.90 \%$ & $0.90 \%$ & $1.80 \%$ & $10.90 \%$ & $34.50 \%$ & $50.90 \%$ & $100.00 \%$ \\
\hline & \multirow[t]{2}{*}{ Baik } & Count & 0 & 0 & 0 & 2 & 12 & 6 & 20 \\
\hline & & $\begin{array}{l}\text { \% within } \\
\text { Motivasi }\end{array}$ & $0.00 \%$ & $0.00 \%$ & $0.00 \%$ & $10.00 \%$ & $60.00 \%$ & $30.00 \%$ & $100.00 \%$ \\
\hline \multirow[t]{2}{*}{ Total } & & Count & 1 & 1 & 2 & 14 & 56 & 71 & 145 \\
\hline & & $\begin{array}{l}\text { \% within } \\
\text { Motivasi }\end{array}$ & $0.70 \%$ & $0.70 \%$ & $1.40 \%$ & $9.70 \%$ & $38.60 \%$ & $49.00 \%$ & $100.00 \%$ \\
\hline
\end{tabular}

Tabel di atas menunjukkan bahwa kelompok alumni yang memiliki motivasi kurang dan cukup, ternyata mayoritas dapat lulus tepat waktu yaitu 8 semester. Justru kelompok alumni yang memiliki motivasi baik ternyata mayoritas lulus 9 semester. Hal ini tentu berbeda dengan apa yang disampaikan oleh Slameto (2010) dimana salah satu faktor internal yang mempengaruhi hasil belajar siswa adalah motivasi. Motivasi adalah pendorong internal individu untuk mencapai tujuan yang akan hendak dicapai. Perbedaan hasil penelitian ini dengan teori, bisa disebabkan karena terlalu lamanya jarak waktu antara penelitian dan pelaksanaan aktivitas mahasiswa. Mahasiswa mulai beraktifitas mulai tahun 2013, sedangkan penelitian baru dilakukan tahun 2020 Sehingga hal itu sangat memungkinkan sekali menyebabkan responden lupa terhadap kondisi sebenarnya pada saat itu. Dan ini tentu akan mempengaruhi hasil penelitian.

\subsubsection{Analisis deskriptif minat dengan ketepatan masa} studi.

Gambaran hubungan minat dengan ketepatan masa studi, dijelaskan dalam tabel 3 berikut ini:

Tabel 3 Hasil analisis deskriptif antara minat dengan ketepatan masa studi

\begin{tabular}{|c|c|c|c|c|c|c|c|c|c|}
\hline & & & \multicolumn{6}{|c|}{ Ketepatan Masa Studi } & \multirow[t]{2}{*}{ Total } \\
\hline & & & $\begin{array}{c}14 \\
\text { Semester }\end{array}$ & $\begin{array}{c}13 \\
\text { Semester }\end{array}$ & $\begin{array}{c}11 \\
\text { Semester }\end{array}$ & $\begin{array}{c}10 \\
\text { Semester }\end{array}$ & 9 Semester & 8 Semester & \\
\hline \multirow[t]{6}{*}{ Minat } & Farmasi & Count & 0 & 0 & 0 & 1 & 2 & 6 & 9 \\
\hline & $\begin{array}{c}\text { Pilihan } \\
\text { ke } 3\end{array}$ & $\%$ within Minat & $0.00 \%$ & $0.00 \%$ & $0.00 \%$ & $11.10 \%$ & $22.20 \%$ & $66.70 \%$ & $100.00 \%$ \\
\hline & Farmasi & Count & 0 & 0 & 0 & 4 & 6 & 10 & 20 \\
\hline & $\begin{array}{c}\text { Pilihan } \\
\text { ke } 2\end{array}$ & \% within Minat & $0.00 \%$ & $0.00 \%$ & $0.00 \%$ & $20.00 \%$ & $30.00 \%$ & $50.00 \%$ & $100.00 \%$ \\
\hline & Farmasi & Count & 1 & 1 & 2 & 9 & 48 & 55 & 116 \\
\hline & $\begin{array}{c}\text { Pilihan } \\
\text { ke } 1\end{array}$ & $\%$ within Minat & $0.90 \%$ & $0.90 \%$ & $1.70 \%$ & $7.80 \%$ & $41.40 \%$ & $47.40 \%$ & $100.00 \%$ \\
\hline \multirow{2}{*}{\multicolumn{2}{|c|}{ Total }} & Count & 1 & 1 & 2 & 14 & 56 & 71 & 145 \\
\hline & & $\%$ within Minat & $0.70 \%$ & $0.70 \%$ & $1.40 \%$ & $9.70 \%$ & $38.60 \%$ & $49.00 \%$ & $100.00 \%$ \\
\hline
\end{tabular}

Tabel di atas menunjukkan bahwa semua kelompok responden, baik yang memiliki minat yang tinggi (menjadikan program studi farmasi sebagai pilihan pertama), atau yang memiliki minat yang sedang (menjadikan prodi farmasi sebagai pilihan kedua saat masuk perguruan tinggi) atau yang memiliki minat yang rendah terhadap prodi farmasi (menjadikan prodi farmais sebagai pilihan yang ketiga), ternyata mayoritas tepat waktu lulus ( 8 semester). Hal tersebut bisa disebabkan karena dengan berjalannya waktu, minat mayoritas mahasiswa berubah, yang semula kurang berminat, tapi setelah menjalaninya dalam kehidupan sehari-hari membuat mereka menjadi minat terhadap prodi farmasi. Dan ini kemudian menstimulir mereka untuk berhasil dalam pembelajaran di prodi farmasi.

\subsubsection{Analisis deskriptif kecerdasan social dengan ketepatan masa studi}

Gambaran hubungan antara keerdasan social dengan ketepatan masa studi dijelaskan dalam tabel berikut ini: 
Tabel 4 Hasil analisis deskriptif antara kecerdasan sosial dengan ketepatan masa studi

\begin{tabular}{|c|c|c|c|c|c|c|c|c|c|}
\hline & & & \multicolumn{6}{|c|}{ Ketepatan Masa Studi } & \multirow[b]{2}{*}{ Total } \\
\hline & & & 14 Semester & 13 Semester & 11 Semester & 10 Semester & 9 Semester & 8 Semester & \\
\hline \multirow{5}{*}{$\begin{array}{c}\text { Kecerdasa } \\
\text { n Sosial }\end{array}$} & \multirow{2}{*}{ Rendah } & Count & 1 & 0 & 0 & 3 & 3 & 12 & 19 \\
\hline & & $\begin{array}{l}\text { \% within } \\
\text { Kecerdasan } \\
\text { Sosial }\end{array}$ & $5.30 \%$ & $0.00 \%$ & $0.00 \%$ & $15.80 \%$ & $15.80 \%$ & $63.20 \%$ & $100.00 \%$ \\
\hline & \multirow[t]{2}{*}{ Sedang } & Count & 0 & 1 & 1 & 8 & 42 & 50 & 102 \\
\hline & & $\begin{array}{l}\text { \% within } \\
\text { Kecerdasan } \\
\text { Sosial }\end{array}$ & $0.00 \%$ & $1.00 \%$ & $1.00 \%$ & $7.80 \%$ & $41.20 \%$ & $49.00 \%$ & $100.00 \%$ \\
\hline & Tinggi & $\begin{array}{l}\text { \% within } \\
\text { Kecerdasan } \\
\text { Sosial }\end{array}$ & $0.00 \%$ & $0.00 \%$ & $4.20 \%$ & $12.50 \%$ & $45.80 \%$ & $37.50 \%$ & $100.00 \%$ \\
\hline \multirow{2}{*}{\multicolumn{2}{|c|}{ Total }} & Count & 1 & 1 & 2 & 14 & 56 & 71 & 145 \\
\hline & & $\begin{array}{l}\text { \% within } \\
\text { Kecerdasan } \\
\text { Sosial }\end{array}$ & $0.70 \%$ & $0.70 \%$ & $1.40 \%$ & $9.70 \%$ & $38.60 \%$ & $49.00 \%$ & $100.00 \%$ \\
\hline
\end{tabular}

Tabel di atas menunjukkan bahwa kelompok responden yang memiliki kecerdasan sosial rendah dan kecerdasan sosial sedang ternyata mayoritasnya bisa lulus tepat waktu (8 semester). Tapi justru kelompok responden yang memiliki kecerdasan sosial tinggi ternyata mayoritasnya lulus pada semester 9. Hal ini tentu tidak sesuai dengan teori. Perbedaan tersebut bisa disebabkan karena terlalu jauhya paut antara realitasnya dan waktu pengambilan data sehingga menyebabkan responden lupa kondisi sebenarnya saat itu.

\subsubsection{Analisis deskriptif hubungan antara kecerdasn} spiritual dengan ketepatan masa studi.

Berikut ini adalah tabel yang menggambarkan tentang hubungan antara kecerdasan spiritual dengan ketepatan masa studi:

Tabel 5. Hasil analisis deskriptif antara kecerdasan spiritual dengan ketepatan masa studi

\begin{tabular}{|c|c|c|c|c|c|c|c|c|c|}
\hline & & & \multicolumn{6}{|c|}{ Ketepatan Masa Studi } & \multirow{2}{*}{ Total } \\
\hline & & & 14 Semester & 13 Semester & 11 Semester & 10 Semester & 9 Semester & 8 Semester & \\
\hline \multirow{6}{*}{$\begin{array}{c}\text { Kecerdasan } \\
\text { Spiritual }\end{array}$} & \multirow[b]{2}{*}{ Kurang } & Count & 1 & 0 & 0 & 3 & 7 & 13 & 24 \\
\hline & & $\begin{array}{c}\text { \% within } \\
\text { Kecerdasan } \\
\text { Spiritual }\end{array}$ & $4.20 \%$ & $0.00 \%$ & $0.00 \%$ & $12.50 \%$ & $29.20 \%$ & $54.20 \%$ & $100.00 \%$ \\
\hline & \multirow[b]{2}{*}{ Cukup } & Count & 0 & 1 & 1 & 9 & 36 & 43 & 90 \\
\hline & & $\begin{array}{c}\text { \% within } \\
\text { Kecerdasan } \\
\text { Spiritual }\end{array}$ & $0.00 \%$ & $1.10 \%$ & $1.10 \%$ & $10.00 \%$ & $40.00 \%$ & $47.80 \%$ & $100.00 \%$ \\
\hline & \multirow[b]{2}{*}{ Baik } & Count & 0 & 0 & 1 & 2 & 13 & 15 & 31 \\
\hline & & $\begin{array}{c}\text { \% within } \\
\text { Kecerdasan } \\
\text { Spiritual }\end{array}$ & $0.00 \%$ & $0.00 \%$ & $3.20 \%$ & $6.50 \%$ & $41.90 \%$ & $48.40 \%$ & $100.00 \%$ \\
\hline \multirow{2}{*}{\multicolumn{2}{|c|}{ Total }} & Count & 1 & 1 & 2 & 14 & 56 & 71 & 145 \\
\hline & & $\begin{array}{c}\text { \% within } \\
\text { Kecerdasan } \\
\text { Spiritual }\end{array}$ & $0.70 \%$ & $0.70 \%$ & $1.40 \%$ & $9.70 \%$ & $38.60 \%$ & $49.00 \%$ & $100.00 \%$ \\
\hline
\end{tabular}

Tabel di atas menunjukkan bahwa semua kelompok responden, baik yang memiliki kecerdasan spiritual rendah, cukup maupun yang baik ternyata mayoritas di antara mereka lulus tepat waktu, yaitu 8 semester. Ada $54,20 \%$ responden yang kecerdasan spiritualnya rendah tapi lulus tepat waktu. Ada 47, 80\% responden yang memiliki kecerdasan spiritual cukup tapi lulus tepat waktu (8 semester). Dan ada 48, 40\% responden yang kecerdasan spiritualnya baik dan lulus tepat waktu. Dan apabila kita lihat ketiganya ternyata yang paling tinggi adalah responden yang kecerdasan spiritualnya rendah dan tepat waktu lulus. Hal ini tentu tidak sesuai dengan teori. yang mengungkapkan bahwa kecerdasan spiritual merupakan konsep pemikiran yang berhubungan bagaimana seseorang pandai dalam mengelola dan mendayagunakan makna-makna, nilai-nilai, dan kualitas-kualitas kehidupan spiritualnya. Ketidaksesuaian mungkin bisa disebabkan karena terlalu lamanya waktu kejadian dengan waktu penelitian.

\subsubsection{Analisis deskriptif antara bidang ilmu yang ditekuni dengan ketepatan masa studi}

Tabel berikut ini menjelaskan tentang gambaran tersebut: 
Tabel 6. Hasil analisis deskriptif antara bidang ilmu dengan ketepatan masa studi

\begin{tabular}{|c|c|c|c|c|c|c|c|c|c|}
\hline & & & & & Ketepata & Iasa Studi & & & Totol \\
\hline & & & 14 Semester & 13 Semester & 11 Semester & 10 Semester & 9 Semester & 8 Semester & Total \\
\hline \multirow{8}{*}{$\begin{array}{l}\text { Bidang } \\
\text { Ilmu }\end{array}$} & \multirow[b]{2}{*}{ Biologi Farmasi } & Count & 1 & 1 & 1 & 2 & 19 & 32 & 56 \\
\hline & & $\begin{array}{c}\text { \% within } \\
\text { Bidang } \\
\text { Ilmu }\end{array}$ & $1.80 \%$ & $1.80 \%$ & $1.80 \%$ & $3.60 \%$ & $33.90 \%$ & $57.10 \%$ & $100.00 \%$ \\
\hline & \multirow[b]{2}{*}{$\begin{array}{l}\text { Farmasi Klinik } \\
\text { dan Komunitas }\end{array}$} & Count & 0 & 0 & 0 & 5 & 21 & 29 & 55 \\
\hline & & $\begin{array}{c}\text { \% within } \\
\text { Bidang } \\
\text { Ilmu }\end{array}$ & $0.00 \%$ & $0.00 \%$ & $0.00 \%$ & $9.10 \%$ & $38.20 \%$ & $52.70 \%$ & $100.00 \%$ \\
\hline & \multirow[b]{2}{*}{ Kimia Farmasi } & Count & 0 & 0 & 0 & 3 & 5 & 1 & 9 \\
\hline & & $\begin{array}{c}\text { \% within } \\
\text { Bidang } \\
\text { Ilmu }\end{array}$ & $0.00 \%$ & $0.00 \%$ & $0.00 \%$ & $33.30 \%$ & $55.60 \%$ & $11.10 \%$ & $100.00 \%$ \\
\hline & \multirow[b]{2}{*}{$\begin{array}{l}\text { Teknologi } \\
\text { Farmasi }\end{array}$} & Count & 0 & 0 & 1 & 4 & 11 & 9 & 25 \\
\hline & & $\begin{array}{c}\text { \% within } \\
\text { Bidang } \\
\text { Ilmu }\end{array}$ & $0.00 \%$ & $0.00 \%$ & $4.00 \%$ & $16.00 \%$ & $44.00 \%$ & $36.00 \%$ & $100.00 \%$ \\
\hline & \multirow[b]{2}{*}{ Total } & Count & 1 & 1 & 2 & 14 & 56 & 71 & 145 \\
\hline & & $\begin{array}{c}\text { \% within } \\
\text { Bidang } \\
\text { Ilmu }\end{array}$ & $0.70 \%$ & $0.70 \%$ & $1.40 \%$ & $9.70 \%$ & $38.60 \%$ & $49.00 \%$ & $100.00 \%$ \\
\hline
\end{tabular}

Tabel di atas meunjukkan bahwa responden yang pada saat tugas akhir menekuni bidang ilmu biologi farmasi atau bidang ilmu farmasi klinik dan komunitas, mayoritas mereka lulus tepat waktu yaitu $57,10 \%$ dan $52,70 \%$. Sedangkan responden yang saat tugas akhir menekuni bidang ilmu kimia farmasi atau bidang ilmu teknologi farmasi, mayoritas mereka lulus setelah 9 semester, yaitu $55,60 \%$ dan $44,00 \%$.

\subsubsection{Analisis deskriptif antara jalur masuk PT dengan ketepatan masa studi}

Tabel berikut ini menjelaskan hubungan antara jalur masuk PT dengan ketepatan masa studi

Tabel 7. Hasil analisis deskriptif antara jalur masuk dengan ketepatan masa studi

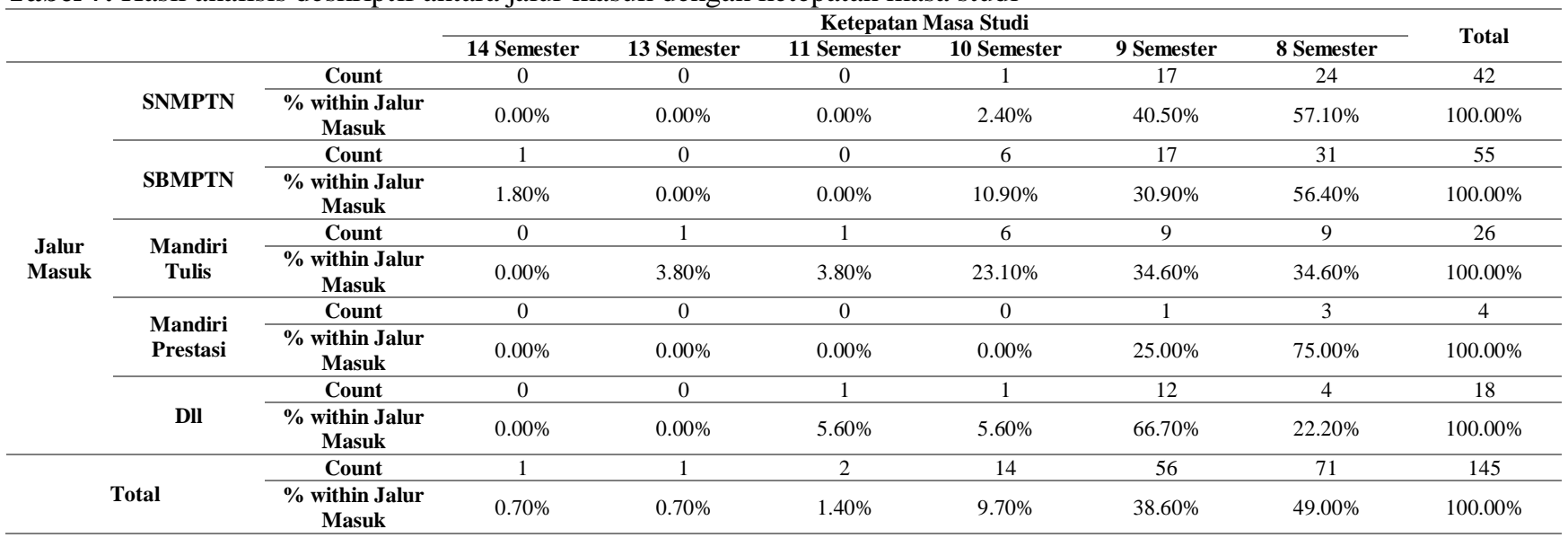

Berdasarkan tabel di atas dapat diketahui bahwa jumlah alumni yang paling banyak lulus tepat waktu adalah alumni dari kelompok jalur mandiri prestasi (75\%), kemudian diikuti jalur SNMPTN $(57,10 \%)$ dan jalur SBMPTN $(56,40 \%)$. Jalur mandiri prestasi di prodi farmasi adalah bagi mereka yang memiliki sejumlah tertentu dari hafalan al-Qur'an. Kedisiplinan mereka dalam menghafal al-Qur;'an kemungkinan mempengaruhi kedisiplinan mereka dalam menempuh studi di prodi farmasi, sehingga menyebabkan kesuksesan mereka berupa lulus tepat waktu.

\subsubsection{Analisis korelasi}

Tabel 8 di bawah ini adalah hasil uji korelasi antara faktor-faktor yang diuji dengan ketepatan waktu lulus: 
Tabel 8. Hasil uji korelasi faktor-faktor yang mempengaruhi ketepatan waktu lulus

\begin{tabular}{ccc}
\hline Faktor yang diuji & Koefisian korelasi & Signifikansi \\
\hline Motivasi & -0.146 & 0.081 \\
\hline Minat & -0.040 & 0.630 \\
\hline Kecerdasan sosial & -0.108 & 0.198 \\
\hline Kecerdasan spiritual & -0.006 & 0.946 \\
\hline Bidang ilmu yang ditekuni & & 0.196 \\
\hline Jalur masuk PT & & 0.082 \\
\hline
\end{tabular}

Tabel di atas menunjukkan bahwa nilai signifikansi yang didapatkan untuk faktor motivasi sebesar 0.081, untuk faktor minat sebesar 0,630, untuk faktor kecerdasan sosial sebesar 0,198 , untuk faktor kecerdasan spiritual sebesar 0,946, untuk bidang ilmu yang ditekuni sebesar 0,196 dan untuk faktor jalur masuk PT sebesar 0,082. Itu menunjukkan bahwa semua nilai signifikansi dari faktor yang diuji, nilainya lebih besar dari nilai alpha (5\%). Dengan demikian H0 diterima atau dengan kata lain tidak ada hubungan yang signifikan antara faktorfaktor yang diuji tersebut dengan ketepatan waktu lulus reponden. Karena tidak ada hubungan yang sigifikan antara faktor-faktor tersebut dengan ketepatan waktu lulus, maka nilai korelasi bisa diabaikan dan tidak perlu dibahas.

Perbedaan hasil penelitian ini dengan teori-teori yang ada, bisa disebabkan oleh beberapa hal, antara lain: 1) adanya jarak yang cukup jauh waktu antara aktivitas mahasiswa saat perkuliahan dengan waktu pengambilan data penelitian ini, yaitu bisa mencapai 5 tahun. Kondisi tersebut bisa menyebabkan kemampuan mengingat responden menjadi rendah, sehingga jawaban yang diberikan tidak sesuai dengan kondisi sebenarnya dari responden. 2) adanya kecenderungan dari alumni yang lulusnya tidak tepat waktu, untuk tidak mengikuti penelitian ini. Hal ini bisa dilihat pada data yang masuk, bahwa hampir semua responden lulus tepat waktu atau setidaknya lulus pada semester 9. Sedangkan alumni yang lulus di atas 9 semester sangat sedikit yang ikut berpartisipasi dalam penelitian ini. Oleh karena itu, untuk penelitian serupa berikutnya disarakan menjadikan semua populasi menjadi sampel dan pengambilan datanya saat mereka baru lulus.

\section{Kesimpulan}

Kesimpulan dari penelitian ini yaitu tidak ada hubungan antara minat, motivasi, kecerdasan spiritual, kecerdasan social, bidang ilmu yang ditekuni dan jalur masuk perguruan tinggi dengan ketepatan waktu lulus mahasiswa program studi farmasi UIN Malang

\section{Ucapan Terima Kasih}

Peneliti mengucapkan terima kasih kepada Kementrian Agama dan Project Management Unit (PMU), The develophment of UIN Maulana Malik Ibrahim Malang Phase II East Java Project.

\section{Referensi}

[1] Kementerian Sekretariat Negara. 2012. Undang-Undang No. 12 Tahun 2012 Tentang Pendidikan Tinggi.

[2] LAM-PTkes. 2019. Pedoman Dan Matriks Penilaian Dokumen Kinerja Dan Laporan Evaluasi Diri Akreditasi Program Studi Sarjana Farmasi Dan Pendidikan Profesi Apoteker, https://lamptkes.org/File-Unduhan-Instrumen9-kriteria (diakses pada tanggal 9 September 2020).

[3] Budiningsih, Asri. 2005. Belajar dan Pembelajaran. Jakarta: Rineka Cipta

[4] Syah, Muhibbin. 1995. Psikologi Pendidikan. Bandung. Bnadung: Remadja Rosda Karya.

[5] Budiningsih, Asri. 2005. Belajar dan Pembelajaran. Jakarta: Rineka Cipta

[6] Goleman, D. 2004. Kecerdasan Emosional. Jakarta: PT. Gramedia Pustaka Utama. 